\title{
Influence of flooding on electrochemical and chemical properties of West African soils
}

\author{
L.T. Narteh, K.L. Sahrawat * \\ West Africa Rice Development Association (WARDA), 01 B.P. 2551, Bouake 01, Ivory Coast
}

Received 2 April 1997; accepted 7 May 1998

\begin{abstract}
An understanding of the influence of flooding on electrochemical and chemical properties of soils provides insight needed in their management for rice production in West Africa. With this objective, the influence of flooding on electrochemical and chemical properties of 15 lowland soils from five rice producing countries in West Africa was studied. The soils were held under flooded conditions in greenhouse pots for 15 weeks. Soil $\mathrm{pH}$ and redox potential (Eh), and anoxic soil solutions drawn weekly were monitored for the changes with respect to major and micronutrients. The electrochemical properties of the soils and their solutions with time tended to stabilize in a narrow range. Soils widely differed in their capacities to release ammonium, $\mathrm{P}, \mathrm{K}, \mathrm{Ca}, \mathrm{Mg}, \mathrm{Fe}$, $\mathrm{Mn}$ and $\mathrm{Zn}$ in soil solution and thus provided useful information regarding the potential deficiencies of plant nutrients, and also, for the occurrence of Fe toxicity to lowland rice. Measurements made on the soil solution phase of the soils provided information for predicting the dynamic relationships among $\mathrm{Eh}, \mathrm{pH}$ and $\mathrm{Fe}$ (II). The soil solution $\mathrm{EC}$ was closely related to the solution concentrations of $\mathrm{K}, \mathrm{Ca}$ and $\mathrm{Mg}$. The soils differed in the pattern and in the amounts of Fe released in soil solution and this information may be helpful in devising a strategy for the management of $\mathrm{Fe}$ toxicity to lowland rice. (C) 1999 Elsevier Science B.V. All rights reserved.
\end{abstract}

Keywords: electrochemical properties; $\mathrm{pH}$; redox potential; soil solution; macro- and micronutrients; lowland rice; Fe toxicity

\section{Introduction}

Rice ranks among the six major food crops of West Africa. Over the last decade the demand for rice has been increasing steadily and this demand has been met mainly through increasing imports. To counter this trend, West Africa

\footnotetext{
* Corresponding author. Tel.: +225-63-45-14; Fax: +225-63-47-14; E-mail: k.sahrawat@cgnet.com
}

0016-7061/99/\$ - see front matter (C) 1999 Elsevier Science B.V. All rights reserved.

PII: S0016-7061(98)00053-6 
Rice Development Association (WARDA) has been engaged with national programs and other international agencies in the sub-region for promoting increased indigenous production of rice. Rice in West Africa is produced in most diverse environments, which may be broadly grouped into uplands, inland swamps, irrigated humid, irrigated Sahelian and mangrove swamp environments.

Apart from a lack of water control that leads to flooding and drought in the same growing cycle, soil nutrient status is a major constraint to rice production in the sub-region. Rice growing in an upland soil faces a harsher growing environment in terms of nutrient status than rice growing in an inland swamp which provides free water on the surface of soil, not only alleviating water shortage, also, increasing the availability of key nutrients and eliminating $\mathrm{Al}$ and Mn toxicities.

For better management of soil, fertilizer and water regime for maximizing rice production in lowland ecology, it is important to understand the unique properties of flooded soils. In West Africa, a large land area under inland valleys, suitable for rice cultivation, remains unexploited (Andriesse and Fresco, 1991). This paper is an attempt to fill the research gap by way of characterizing the influence of flooding on the electrochemical and chemical properties of diverse wetland rice soils from five rice producing countries in West Africa.

\section{Materials and methods}

\subsection{Soils}

Surface $(0-15 \mathrm{~cm})$ samples of rice growing soils were collected from 15 locations in five rice producing countries in West Africa. Information about the location, classification and physical and chemical characteristics of the soils is summarized in Table 1. Chemical properties of the 15 soils, relevant to the present study .are summarized in Table 2. For the soil analyses, $\mathrm{pH}$ was measured by a glass electrode using soil to water or $\mathrm{KCl}$ solution ratio of 1:2.5. Particle-size analysis was made using the pipette method (Gee and Bauder, 1986). Organic C was determined by the Walkley-Black method (Nelson and Sommers, 1982), and total $\mathrm{N}$ and ammonium and nitrate $\mathrm{N}$ were determined as described by Bremner (1965a,b). Total P was determined colorimetrically after digestion of soil samples with nitric and perchloric acids, and Olsen and Bray 1 extractable P were determined as described by Olsen and Sommers (1982). Cation exchange capacity (CEC) was determined as described by Chapman (1965) and extractable Fe, Mn and $\mathrm{Zn}$ were determined as described by Lindsay and Norvell (1978). Exchangeable bases and Al in soil samples were also determined (Jackson, 1967).

A wide variety of soils was represented. Soils 1-12 were located in the forest and savanna agroecological zones and have had a known history of causing $\mathrm{Fe}$ 
toxicity to the lowland rice crop. Soils 13 and 14 were located in the forestsavanna transition zone, and soil 15 was located in the forest agroecological zone. Soil 13 was without much Fe toxicity. Soils 14 and 15 were upland soils and were included to provide further diversity in soil characteristics.

\subsection{Determination of changes in electrochemical and chemical properties of} flooded soils

The changes with time in electrochemical and chemical properties of the soils as affected by flooding were followed. Samples of $10 \mathrm{~kg}$ dry weight were kept submerged with distilled water in glazed pots fitted with a system at the base of each pot for collecting the soil solution under gravity. It consisted of rubber stoppers with sintered glass tubes passing through them, bent vertically downwards to allow the collection of soil solution. A layer of $3-5 \mathrm{~cm}$ standing water over the samples was maintained throughout the period of study. Permanently fitted in the pots were platinum electrodes connected to $\mathrm{Cu}$ wire and inserted 8 $\mathrm{cm}$ deep into the soil to allow for the measurement of soil redox potential (Eh) by a combined $\mathrm{pH}-\mathrm{Eh}$ meter. Soil $\mathrm{pH}$ was also measured.

Soil solutions were collected under anoxic conditions from the flooded 15 soils at weekly intervals using $250 \mathrm{ml}$ Erlenmeyer flasks fitted with glass tubes in rubber stoppers. The flasks were filled with $\mathrm{N}_{2}$ gas. Soil solution was analysed for $\mathrm{Fe}$ (II) immediately using atomic absorption spectrophotometer. If immediate analysis was not possible, the soil solutions were acidified $(\mathrm{pH} 3)$ with dilute $\mathrm{HCl}$ and kept under refrigeration $\left(4^{\circ} \mathrm{C}\right)$. Soil solutions were analysed for $\mathrm{pH}, \mathrm{Eh}$, and macro and micronutrient elements for 15 weeks.

\section{Results and discussion}

\subsection{Chemical properties of the soils}

The 15 soils studied had a wide range in initial $\mathrm{pH}(4.3-7.7)$, organic $\mathrm{C}$ (7.4-46.0 $\mathrm{g} \mathrm{kg}^{-1}$ ), total $\mathrm{N}\left(500-3300 \mathrm{mg} \mathrm{N} \mathrm{kg}^{-1}\right.$ ) and extractable plant nutrients (Tables 1 and 2). Generally, they were acidic in reaction and had a net negative charge at the natural soil reaction as indicated by the fall in $\mathrm{pH}$ between water and $\mathrm{KCl}$ solution. Soils 1, 6 and 15 recorded high exchangeable $\mathrm{Al}$ ( $>80$ $\mathrm{mg} \mathrm{kg} \mathrm{kg}^{-1}$ soil) and, when in use for upland rice production, they may cause $\mathrm{Al}$ toxicity and P deficiency, as indeed has been observed in the case of soils 6 and 15. Most of the soils were low in DTPA extractable Zn. Results on extractable P showed wide differences according to the method of extraction, i.e., Bray 1 $\left(0.03 \mathrm{~N} \mathrm{NH}_{4} \mathrm{~F}+0.025 \mathrm{~N} \mathrm{HCl}\right)$ and Olsen $(0.5 \mathrm{M} \mathrm{NaHCO})_{3}$. It has been suggested that, for lowland rice soils, an extractant that specifically extracts $\mathrm{Fe}-\mathrm{P}$ in the air-dry samples should be suitable for predicting availability of $\mathrm{P}$ to 
Table 1

Physical and chemical properties of the soils used in the study

\begin{tabular}{|c|c|c|c|c|c|c|c|}
\hline $\begin{array}{l}\text { Soil } \\
\text { no. }\end{array}$ & Location & $\begin{array}{l}\text { Classification } \\
(\mathrm{FAO}, 1988)\end{array}$ & Texture & $\mathrm{pH}$ & $\begin{array}{l}\text { Clay } \\
\left(\mathrm{g} \mathrm{kg}^{-1}\right)\end{array}$ & $\begin{array}{l}\text { Org. C } \\
\left(\mathrm{g} \mathrm{kg}^{-1}\right)\end{array}$ & $\begin{array}{l}\text { CEC } \\
\left(\mathrm{cmol} \mathrm{kg}^{-1}\right)\end{array}$ \\
\hline 1 & $\begin{array}{l}\text { Edozhighi, Nigeria } \\
9^{\circ} 06^{\prime} \mathrm{N} 5^{\circ} 59^{\prime} \mathrm{E}\end{array}$ & Dystric Gleysol & Silt loam & 4.3 & 163 & 7.8 & 5.6 \\
\hline 2 & $\begin{array}{l}\text { Ikot-Obong, Nigeria } \\
5^{\circ} 01^{\prime} \mathrm{N} 7^{\circ} 56^{\prime} \mathrm{E}\end{array}$ & Dystric Gleysol & Loamy sand & 5.2 & 53 & 11.4 & 1.4 \\
\hline 3 & $\begin{array}{l}\text { Ifaki-Ekiti, Nigeria } \\
7^{\circ} 14^{\prime} \mathrm{N} 5^{\circ} 8^{\prime} \mathrm{E}\end{array}$ & Eutric Gleysol & Clay & 7.7 & 510 & 46.0 & 30.0 \\
\hline 4 & $\begin{array}{l}\text { Itoikin, Nigeria } \\
6^{\circ} 36^{\prime} \mathrm{N} 3^{\circ} 32^{\prime} \mathrm{E}\end{array}$ & Dystric Gleysol & Silt loam & 4.9 & 215 & 9.8 & 6.5 \\
\hline 5 & $\begin{array}{l}\text { Fumesua, Ghana } \\
6^{\circ} 54^{\prime} \mathrm{N} 1^{\circ} 35^{\prime} \mathrm{W}\end{array}$ & Gleyic Arenosol & Loamy sand & 5.4 & 45 & 8.8 & 0.8 \\
\hline 6 & $\begin{array}{l}\text { Kikam, Ghana } \\
4^{\circ} 53^{\prime} \mathrm{N} 2^{\circ} 14^{\prime} \mathrm{W}\end{array}$ & Dystric Gleysol & Clay loam & 5.1 & 350 & 35.2 & 17.0 \\
\hline 7 & $\begin{array}{l}\text { Kou valley, Burkina Faso } \\
11^{\circ} 11^{\prime} \mathrm{N} 4^{\circ} 18^{\prime} \mathrm{W}\end{array}$ & Dystric Gleysol & Silt loam & 6.1 & 262 & 13.4 & 11.1 \\
\hline 8 & $\begin{array}{l}\text { Karfiguela, Burkina Faso } \\
10^{\circ} 36^{\prime} \mathrm{N} 4^{\circ} 45^{\prime} \mathrm{W}\end{array}$ & Dystric Gleysol & Silt loam & 5.6 & 308 & 9.2 & 14.5 \\
\hline
\end{tabular}


9 Korhogo, Ivory Coast $9^{\circ} 22^{\prime}$ N $5^{\circ} 31^{\prime} \mathrm{W}$

10 Kilissi, Rep. of Guinea $10^{\circ} 3^{\prime} \mathrm{N} 12^{\circ} 49^{\prime} \mathrm{W}$

11 Farannah, Rep. of Guinea $10^{\circ} 01^{\prime} \mathrm{N} 10^{\circ} 47^{\prime} \mathrm{W}$

12 Kissidougou, Rep. of Guinea $9^{\circ} 48^{\prime} \mathrm{N} 10^{\circ} 8^{\prime} \mathrm{W}$

13 Bouake, Ivory Coast $7^{\circ} 42^{\prime} \mathrm{N} 5^{\circ} 00^{\prime} \mathrm{W}$

14 Bouake, Ivory Coast $7^{\circ} 42^{\prime} \mathrm{N} 5^{\circ} 00^{\prime} \mathrm{W}$

15 Man, Ivory Coast $7^{\circ} 31^{\prime} \mathrm{N} 7^{\circ} 37^{\prime} \mathrm{W}$

$\begin{array}{llcccc}\text { Dystric Gleysol } & \text { Silt loam } & 5.4 & 275 & 20.0 & 12.5 \\ \text { Dystric Gleysol } & \begin{array}{l}\text { Sandy clay } \\ \text { loam }\end{array} & 5.6 & 220 & 25.2 & 12.7 \\ \text { Dystric Gleysol } & \begin{array}{l}\text { Silty clay } \\ \text { loam }\end{array} & 5.5 & 330 & 23.2 & 16.8 \\ \text { Dystric Gleysol } & \text { Silt } & 5.3 & 60 & 19.6 & 8.8 \\ \text { Dystric Gleysol } & \text { Clay loam } & 6.1 & 318 & 23.0 & 8.7 \\ \text { Eutric Leptosol } & \text { Sandy loam } & 6.3 & 88 & 7.4 & 2.0 \\ \text { Ferric Acrisol } & \text { Loam } & 5.0 & 298 & 15.6 & 8.5\end{array}$

8.5 
Table 2

Additional chemical characteristics of the 15 West African soils used in the study

\begin{tabular}{|c|c|c|c|c|c|c|c|c|c|c|c|}
\hline \multirow{2}{*}{$\begin{array}{l}\text { Soil } \\
\text { no. }\end{array}$} & \multicolumn{2}{|l|}{ Total } & \multirow{2}{*}{$\begin{array}{l}\text { Bray1 } \\
\mathrm{P} \\
\left(\mathrm{mg} \mathrm{kg}^{-1}\right)\end{array}$} & \multirow{2}{*}{$\begin{array}{l}\text { Olsen } \\
\begin{array}{l}\mathrm{P} \\
\left(\mathrm{mg} \mathrm{kg}^{-1}\right)\end{array}\end{array}$} & \multicolumn{4}{|l|}{ Extractable } & \multicolumn{3}{|l|}{ Exchangeable } \\
\hline & $\begin{array}{l}\mathrm{N} \\
\left(\mathrm{mg} \mathrm{kg}^{-1}\right)\end{array}$ & $\begin{array}{l}\mathrm{P} \\
\left(\mathrm{mg} \mathrm{kg}^{-1}\right)\end{array}$ & & & $\begin{array}{l}\mathrm{Fe} \\
\left(\mathrm{mg} \mathrm{kg}^{-1}\right)\end{array}$ & $\begin{array}{l}\mathrm{Mn} \\
\left(\mathrm{mg} \mathrm{kg}^{-1}\right)\end{array}$ & $\begin{array}{l}\mathrm{Zn} \\
\left(\mathrm{mg} \mathrm{kg}^{-1}\right)\end{array}$ & $\begin{array}{l}\mathrm{Al} \\
\left(\mathrm{mg} \mathrm{kg}^{-1}\right)\end{array}$ & $\begin{array}{l}\mathrm{K} \\
\left(\mathrm{c} \mathrm{mol} \mathrm{kg}{ }^{-1}\right)\end{array}$ & $\begin{array}{l}\mathrm{Ca} \\
\left(\mathrm{c} \mathrm{mol} \mathrm{kg}{ }^{-1}\right)\end{array}$ & $\begin{array}{l}\mathrm{Mg} \\
\left(\mathrm{c} \mathrm{mol} \mathrm{kg}{ }^{-1}\right)\end{array}$ \\
\hline 1 & 750 & 162 & 8 & 20 & 339 & 19 & 1 & 85 & 0.10 & 0.80 & 0.23 \\
\hline 2 & 600 & 80 & 8 & 10 & 63 & 1 & 1 & 30 & 0.06 & 0.36 & 0.06 \\
\hline 3 & 3300 & 1125 & 3 & 104 & 178 & 66 & 40 & 5 & 0.17 & 14.80 & 3.04 \\
\hline 4 & 900 & 163 & 8 & 14 & 178 & 10 & 1 & 40 & 0.07 & 0.88 & 0.33 \\
\hline 5 & 700 & 89 & 12 & 11 & 112 & 4 & 1 & 10 & 0.04 & 0.66 & 0.11 \\
\hline 6 & 2700 & 448 & 5 & 25 & 264 & 4 & 1 & 165 & 0.15 & 0.70 & 0.28 \\
\hline 7 & 1100 & 176 & 2 & 11 & 295 & 5 & 1 & 5 & 0.11 & 1.84 & 0.12 \\
\hline 8 & 800 & 248 & 1 & 14 & 340 & 74 & 2 & 20 & 0.13 & 1.78 & 1.08 \\
\hline 9 & 1500 & 463 & 1 & 30 & 486 & 29 & 2 & 30 & 0.07 & 0.84 & 0.28 \\
\hline 10 & 1800 & 545 & 5 & 50 & 485 & 33 & 1 & 50 & 0.04 & 0.96 & 0.17 \\
\hline 11 & 1500 & 300 & 1 & 13 & 415 & 15 & 1 & 45 & 0.03 & 0.96 & 0.48 \\
\hline 12 & 1200 & 500 & 4 & 11 & 236 & 3 & 1 & 30 & 0.04 & 0.64 & 0.35 \\
\hline 13 & 1800 & 180 & 4 & 18 & 284 & 57 & 1 & 5 & 0.04 & 0.62 & 0.36 \\
\hline 14 & 500 & 211 & 10 & 13 & 24 & 22 & 6 & 5 & 0.10 & 1.03 & 0.67 \\
\hline 15 & 1200 & 234 & 6 & 10 & 166 & 3 & 1 & 85 & 0.08 & 0.88 & 0.44 \\
\hline
\end{tabular}


wetland rice (Cholitikul and Tyner, 1971). Ekpete (1976) evaluated several chemical methods for assessing the available $\mathrm{P}$ status in 13 waterlogged soils ( $\mathrm{pH}$ 4.2-6.1). He concluded that Olsen's method was better than all other methods because it better predicted the availability of $\mathrm{P}$ under waterlogged conditions from the analysis performed on air-dry samples.

Among the 15 soils under study, soil 3 was rather atypical as it was highest in organic C, total N, CEC and total and extractable P levels as compared with the rest of the soils. For the presentation of results, the soils were grouped into three groups on the basis of their organic $C$ and clay contents. Soils 3, 6, 9, 10 and 13 were in one group and contained relatively high amounts of organic $\mathrm{C}$ and clay. Soils $1,4,7,11,12,15$ and 8 formed the second group and were generally low to moderate in organic $\mathrm{C}$ and silt loam in texture. The third group consisted of soils 2, 5 and 14 and they were low in organic $\mathrm{C}$ and loamy sand or sandy loam in texture.

\subsection{Changes in the electrochemical properties}

\subsection{1. $p H$}

Flooding of samples narrowed the soil and soil solution pH (Figs. 1 and 2). At the first week of flooding, the soil pH ranged between 5.6 (soil 1) and 7.4 and they were narrowed to range between 6.8 (soil 15) and 7.7 at the 15 th week of flooding (Fig. 1). The soil solution $\mathrm{pH}$ ranged between 4.9 (soil 11) and 7.8 (soil 8) at the first week, and recorded a range of 5.6 (soil 2) to 8.2 (soil 13) at the 15th week of flooding (Fig. 2). The observed increase in soil and solution $\mathrm{pH}$ as a result of submergence into water is well known (Ponnamperuma, 1972) and attributed to the consumption of protons during reduction processes. However, Yu (1985) observed that the relationship between soil $\mathrm{pH}$ and soil reduction was not a simple one. He noted that upon submergence, production of acid radicals, especially $\mathrm{COO}^{-}$and organic radicals may partly compensate for the $\mathrm{pH}$-raising effect of reduction in acid soils or may cause lowering of $\mathrm{pH}$ in the case of alkaline soils.

The optimum $\mathrm{pH}$, measured in soil solution, for rice is 6.6 at which microbial release of $\mathrm{N}, \mathrm{P}$ and their availability is high. The supplies of micronutrient elements such as $\mathrm{Cu}, \mathrm{Zn}$ and $\mathrm{Mo}$ are adequate and the concentrations of reduction products such as organic acids and $\mathrm{Al}, \mathrm{Mn}$ and $\mathrm{CO}_{2}$ are below toxic levels (Ponnamperuma, 1965).

\subsubsection{Redox potential (Eh)}

A wide range of $482 \mathrm{mV}$ soil Eh was recorded at the first week of flooding with soil 12 recording an Eh of $476 \mathrm{mV}$ and soil 3 of $-6 \mathrm{mV}$. By 15th week, the range had drastically reduced to between $40 \mathrm{mV}$ (soil 14) and $-45 \mathrm{mV}$ (soil 3) (Fig. 3). A similar trend was recorded in soil solution Eh. Soil 12 recorded $184 \mathrm{mV}$ at the first week, while $-20 \mathrm{mV}$ was recorded for soil 2 (Fig. 4). By 


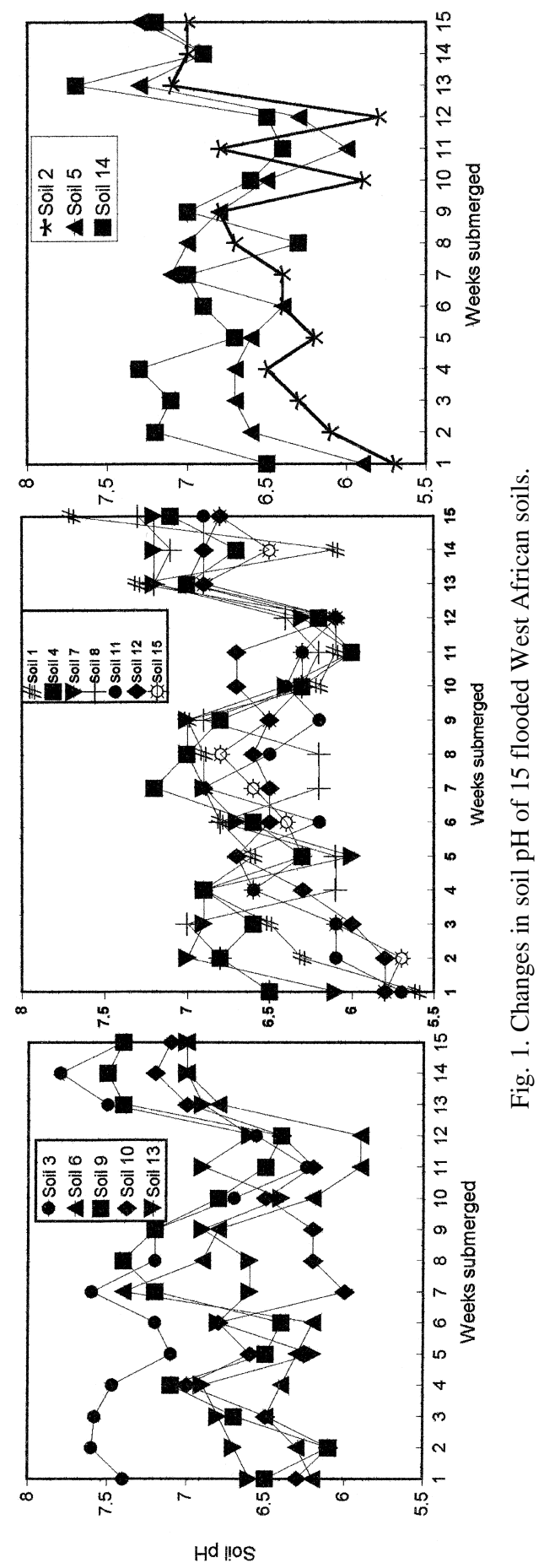



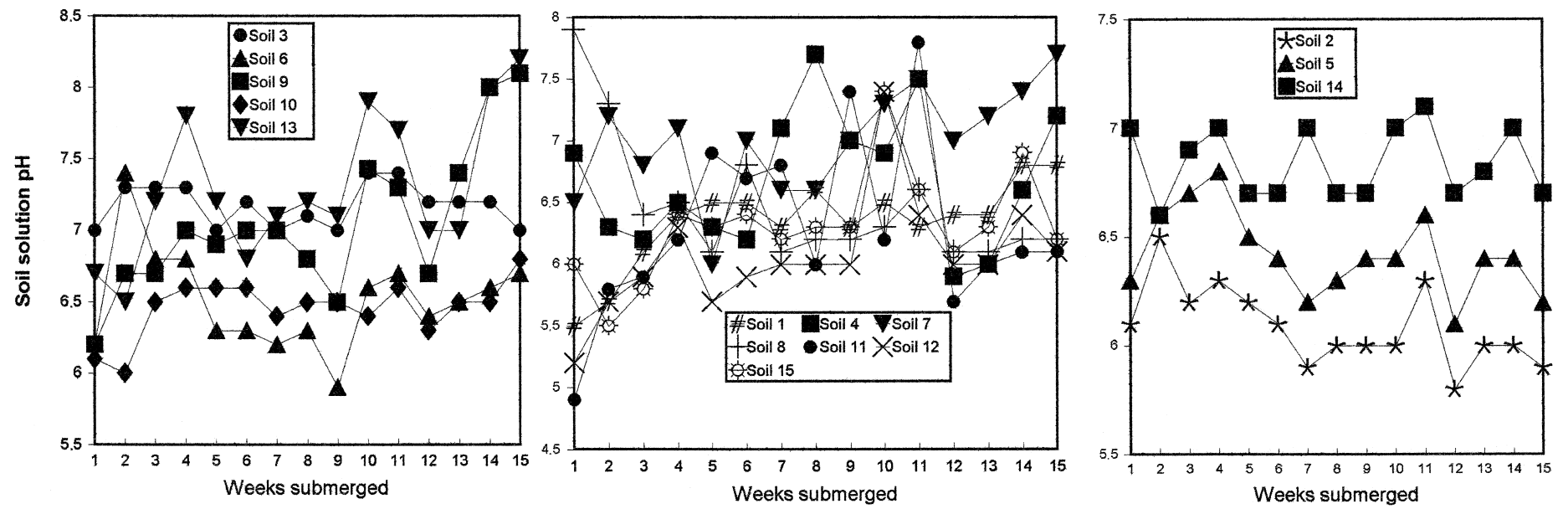

Fig. 2. Changes in solution $\mathrm{pH}$ of 15 flooded West African soils. 


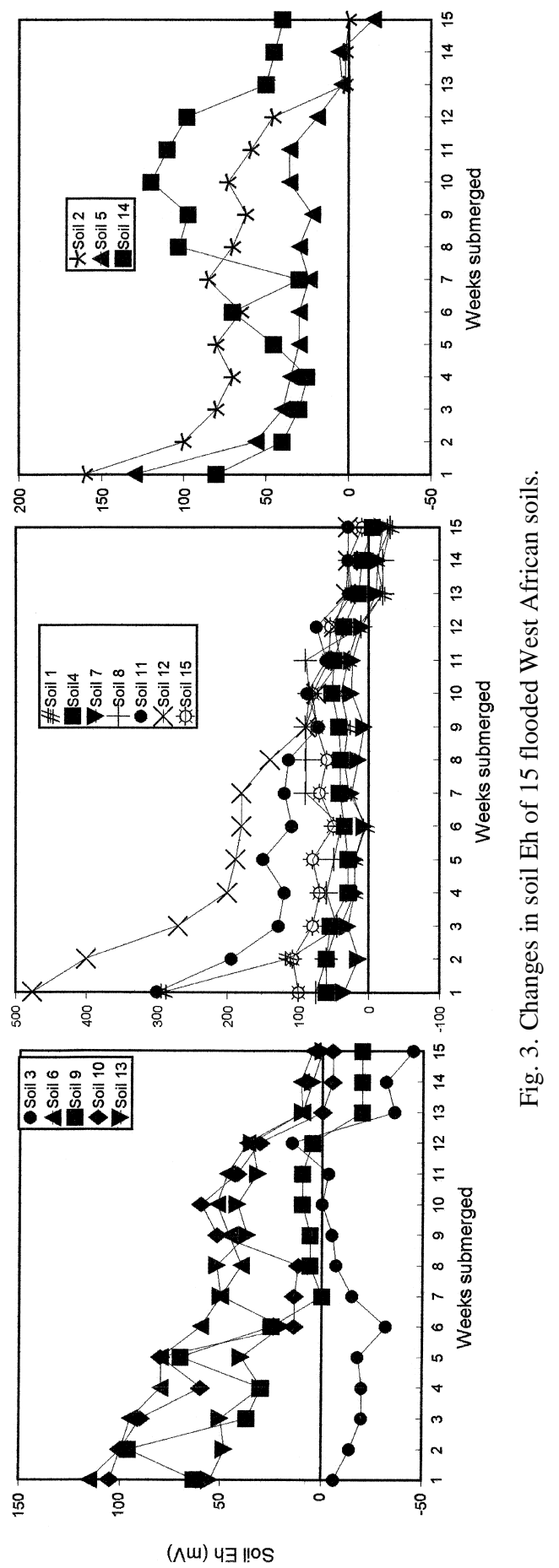




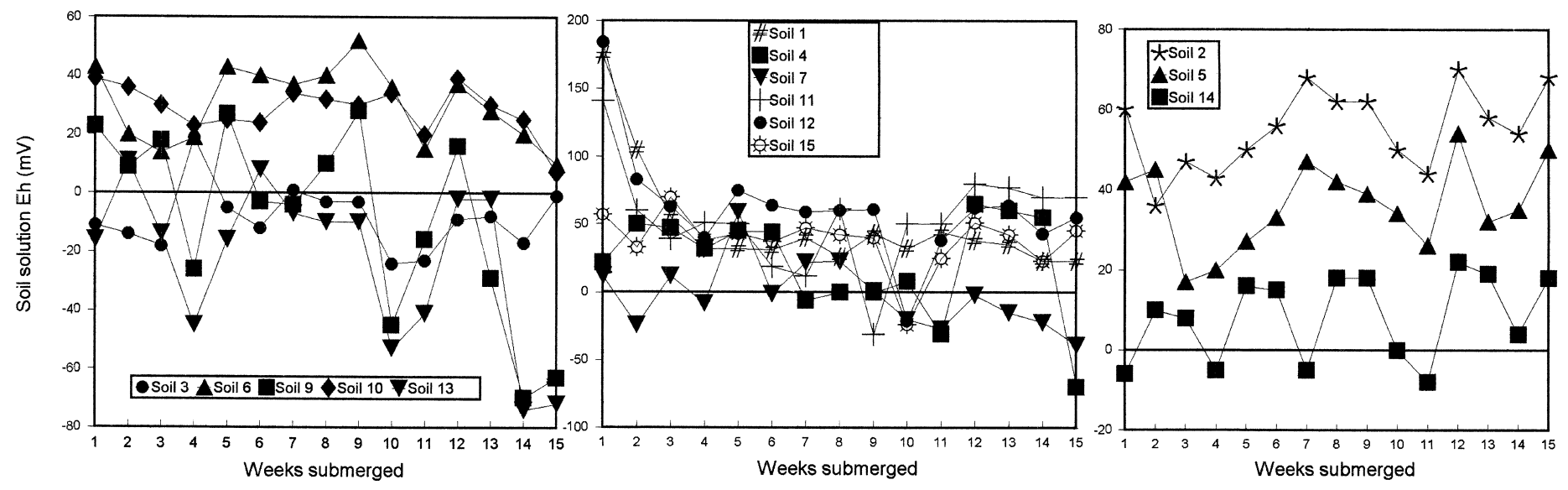

Fig. 4. Changes in solution Eh of 15 flooded West African soils. 
15 th week, a still narrower range was observed in the soil solution Eh. The kinetics of soil solution Eh were more chaotic than the soil phase. Generally, the soil and soil solution Eh decreased in all soils. The differences in the trends are dependent on organic matter content of the soils and the amounts of reducible Fe and Mn (Ponnamperuma, 1972).

\subsection{3. $p H-$ Eh relationship}

The relationship between $\mathrm{Eh}$ or $\mathrm{pE}(\mathrm{pE}=\mathrm{Eh} / 0.059)$ and $\mathrm{pH}$ for soils 3 and 12, for soil and solution phases, which recorded the highest and lowest Eh during 15 weeks of submergence were described by the following regression equations:

Flooded soils

$$
\begin{aligned}
& \text { Soil 3: soil } \mathrm{pE}=2.5-0.37 \text { soil } \mathrm{pH} \quad(r=-0.642 ; p<0.012) \\
& \text { Soil 12: soil } \mathrm{pE}=33.0-4.70 \text { soil } \mathrm{pH} \quad(r=-0.735 ; p<0.002)
\end{aligned}
$$

Soil solution phase

Soil 3: solution $\mathrm{pE}=5.20-0.76$ solution $\mathrm{pH} \quad(r=-0.817 ; p<0.001)$

Soil 12: solution $\mathrm{pE}=9.40-1.20$ solution $\mathrm{pH}$

$$
\times(r=-0.992 ; p<0.001)
$$

Our results are in accord with those reported for the studies carried out in the Philippines by Ponnamperuma (1965) who contended that soil solution measurements are thermodynamically more meaningful because they are potentials of a homogenous phase in equilibrium with the solid and gaseous phases of the soil. On the other hand, there is poor reproducibility in Eh between two electrodes on the same soil. Our results corroborate his conclusions in that platinum electrode measurements indicate localized potentials.

Our results also showed that the changes in soil solution $\mathrm{pH}$ generally corresponded to changes in solution Eh. The stability in the changes in the $\mathrm{Eh}-\mathrm{pH}$ relationships was recorded at the 4 th week after submergence, and is presented in Fig. 5, was described by the following equation:

$$
\Delta \mathrm{Eh}=-16-48 \Delta \mathrm{pH} ; \quad R^{2}=0.84 \quad(p<0.001)
$$

These relationships could allow for the calculation of the changes in $\mathrm{pH}$ as long as the changes in Eh are known or vice versa.

\subsubsection{Electrical conductivity (EC)}

The changes in solution EC of the 15 soils are shown in Fig. 6. After 1 week of flooding, the EC ranged from $0.11 \mathrm{mS} \mathrm{cm}^{-1}$ (soil 5) to $2.07 \mathrm{mS} \mathrm{cm}^{-1}$ (soil 3). There were no appreciable changes with time in the EC trends. 


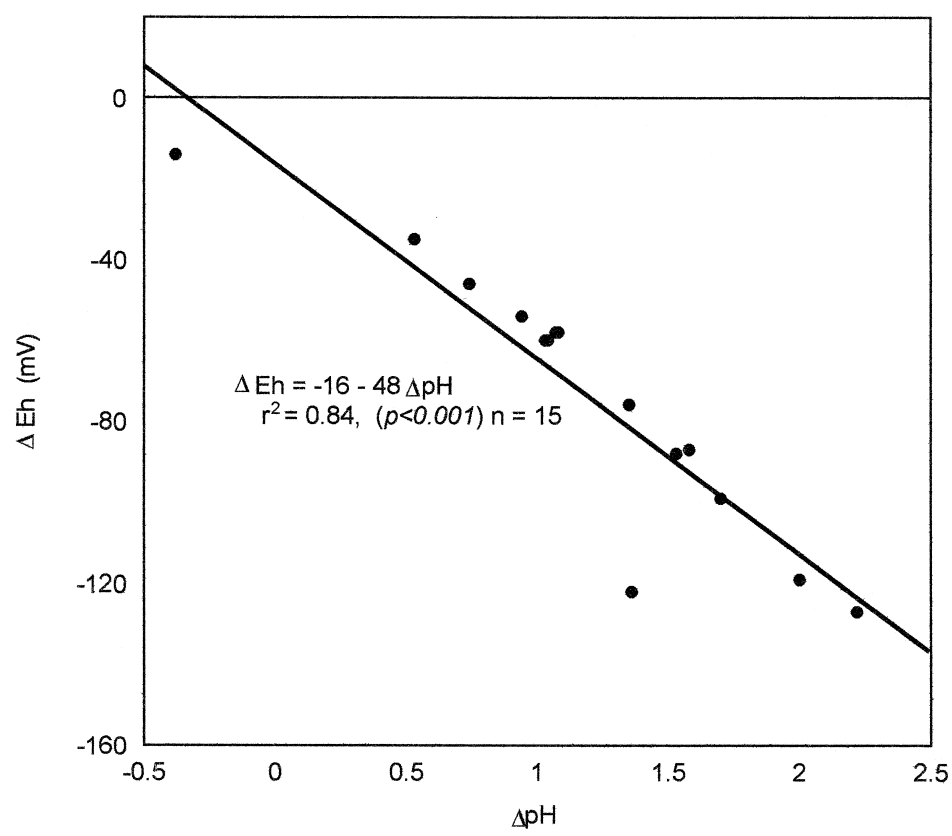

Fig. 5. Relationship between change in solution $\mathrm{pH}$ and change in solution Eh of 15 flooded West African soils at 4 weeks of flooding.

Considering all the 15 soils at the 4th week of flooding, it was found that the soil solution EC was correlated with the concentrations of the basic cations, namely, $\mathrm{Ca}, \mathrm{Mg}$ and $\mathrm{K}$ rather than with $\mathrm{Fe}, \mathrm{Mn}$ or $\mathrm{Zn}$ (Table 3). The importance of $\mathrm{Ca}$ in contributing to the soil solution EC was clearly evident (Fig. 7). At 4th week of flooding, the mean EC value of soil solution was highly significantly correlated with the mean total concentration of $\mathrm{Ca}, \mathrm{Mg}$ and $\mathrm{K}$ in the soil solution $(r=0.91)$ (Fig. 8). These results are in accord with the results reported for the flooded Asian soils (Ponnamperuma, 1965). In most samples, the concentrations of cations, especially of $\mathrm{Ca}$, in soil solution fell sharply by the 8th week, indicating another phase of dynamic equilibrium. It was shown that the relationship, as indicated by coefficients of correlation, between soil solution EC and $\mathrm{K}$ concentration in soil solution improved over that observed at the 4th week of flooding, and also over those of $\mathrm{Ca}$ and $\mathrm{Mg}$ (Figs. 9 and 10).

The close relationship observed between soil solution EC and the concentration of basic cations in the flooded soils is therefore, very important, and has a direct influence in the use of fertilizers and amendments for rice production in the lowland swamp ecology in West Africa. Rice soils in the submerged state mobilize large concentrations of $\mathrm{Fe}$ and $\mathrm{Mn}$ into soil solution which displace cations such as $\mathrm{Ca}, \mathrm{Mg}$ and $\mathrm{K}$ from the soil exchange complex, increasing their concentration in the soil solution. A slight increase in the concentration of water-soluble $\mathrm{K}$ brought about by cation exchange may be important in the 

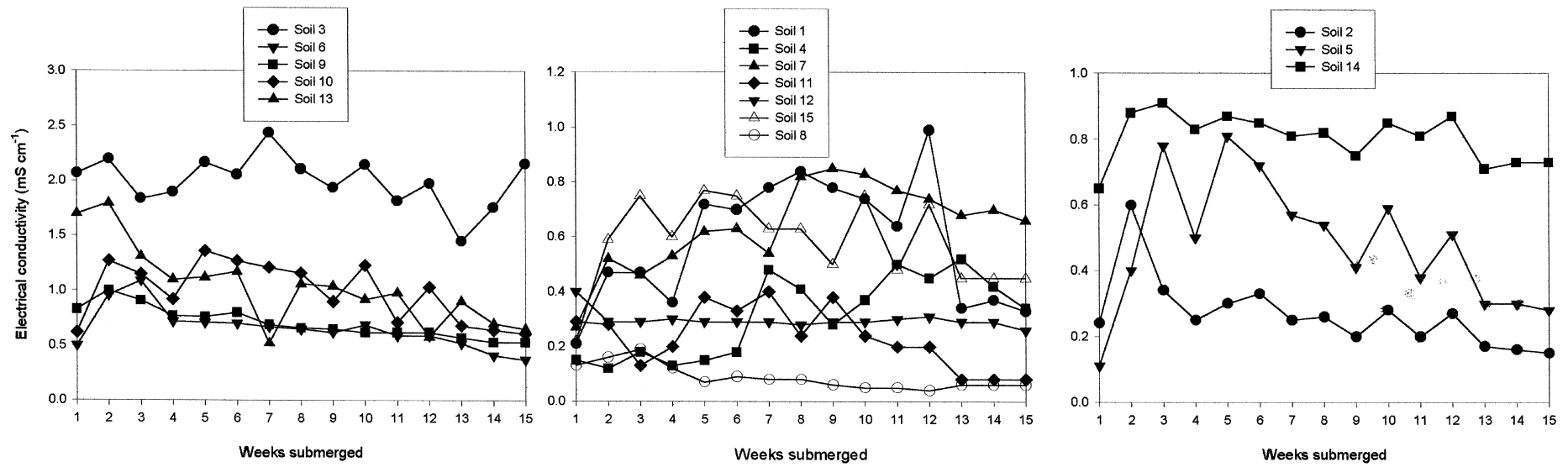

Fig. 6. Changes in solution electrical conductivity (EC) of 15 flooded West African soils. 
Table 3

Correlations between the soil solution EC of 15 flooded West African soils and the concentration of important nutrient elements at 4 weeks of flooding

\begin{tabular}{lc}
\hline Nutrient element & Correlation coefficient $(r)$ \\
\hline $\mathrm{K}$ & $0.85(p<0.001)$ \\
$\mathrm{Ca}$ & $0.86(p<0.001)$ \\
$\mathrm{Mg}$ & $0.84(p<0.001)$ \\
Total K+ Ca+Mg & $0.91(p<0.001)$ \\
$\mathrm{Mean} \mathrm{K}+\mathrm{Ca}+\mathrm{Mg}$ & $0.91(p<0.001)$ \\
$\mathrm{Ammonium} \mathrm{N}$ & $0.62(p<0.001)$ \\
$\mathrm{Mn}$ & $0.12(p<1.00)$ \\
$\mathrm{Fe}(\mathrm{II})$ & $-0.16(p<1.00)$ \\
$\mathrm{Zn}$ & $-0.35(p<0.20)$ \\
\hline
\end{tabular}

Probability levels of significance $(p)$ are shown in the parentheses.

nutrition of rice plant, although loss of $\mathrm{Ca}$ and $\mathrm{Mg}$ displaced from the soil exchange complex may lead to soil acidification (Brinkman, 1970).

\subsection{Changes in chemical properties}

\subsubsection{Changes in the concentration of ammonium $N$ in soil solution}

The production of ammonium is the key process for the $\mathrm{N}$ nutrition of lowland rice because the $\mathrm{N}$ mineralization process stops at ammonium production in the submerged rice soils.

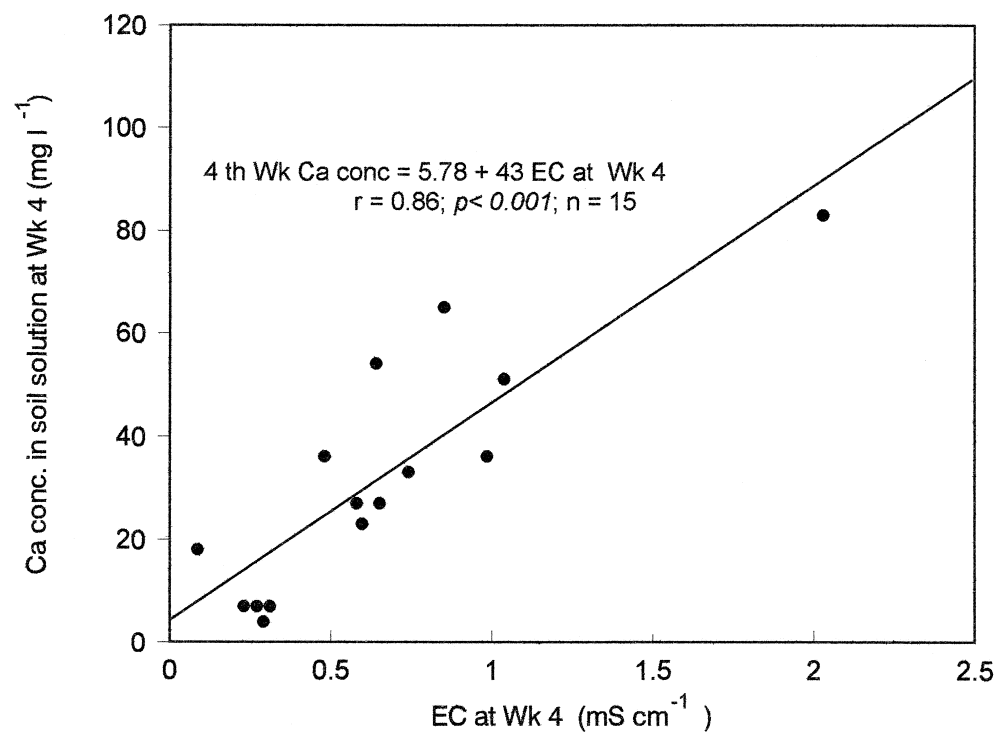

Fig. 7. Relationship between Ca concentration in soil solution and the solution EC of 15 flooded West African soils at 4 weeks of flooding. 


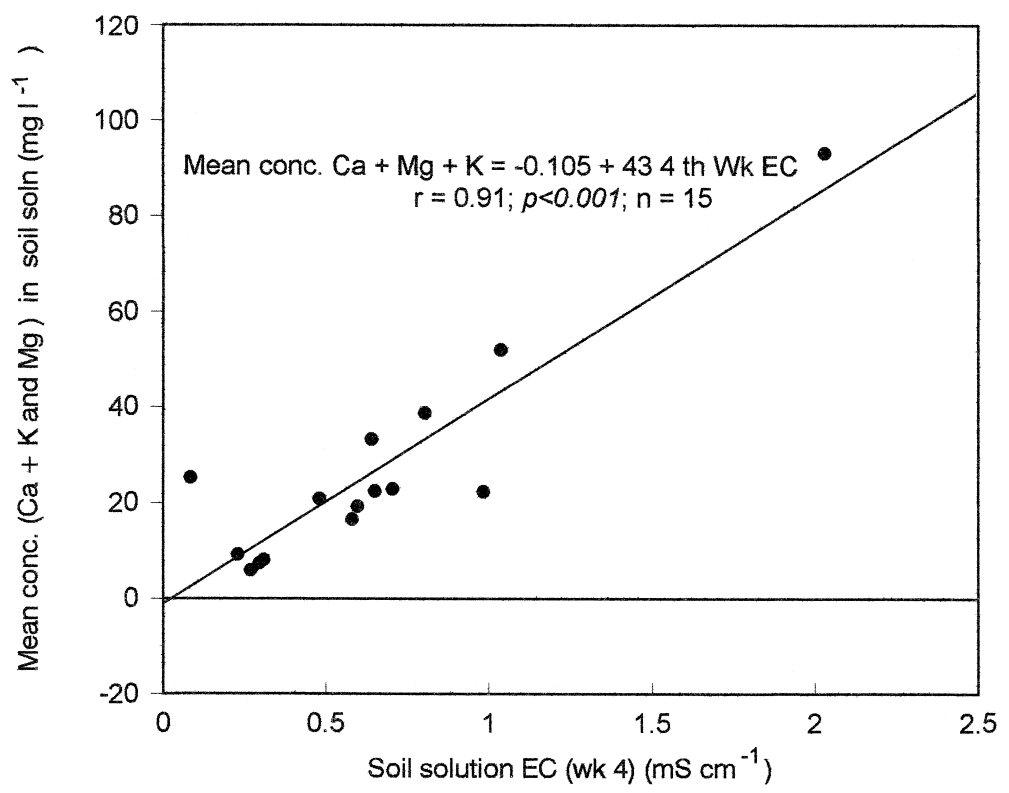

Fig. 8. Relationship between mean total concentration of $\mathrm{Ca}, \mathrm{Mg}$ and $\mathrm{K}$ in soil solution and the solution EC of 15 flooded West African soils at 4 weeks of flooding.

The changes in the concentration of ammonium in soil solution of the 15 soils are shown in Fig. 11, indicated that the soils had a wide range in the amounts of ammonium $\mathrm{N}$ mobilized in soil solution. Based on the mean ammonium values

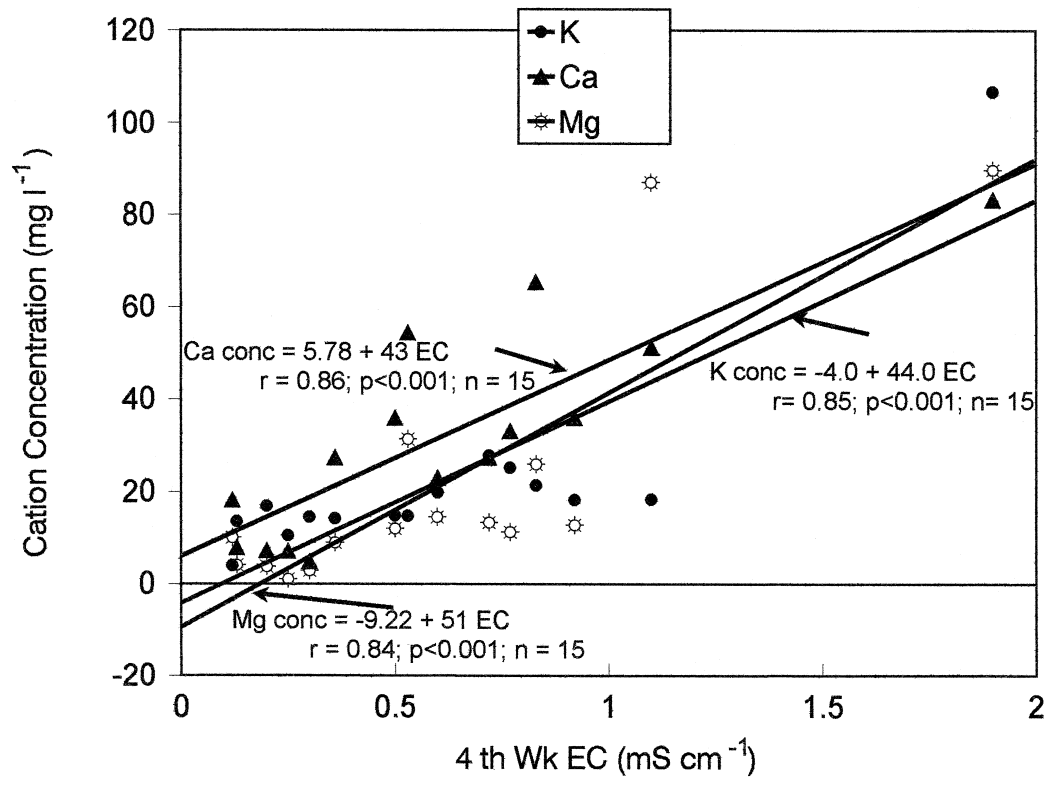

Fig. 9. Relationships between $\mathrm{K}, \mathrm{Ca}$ and $\mathrm{Mg}$ concentration in soil solution and the solution EC of 15 flooded West African soils at 4 weeks of flooding. 


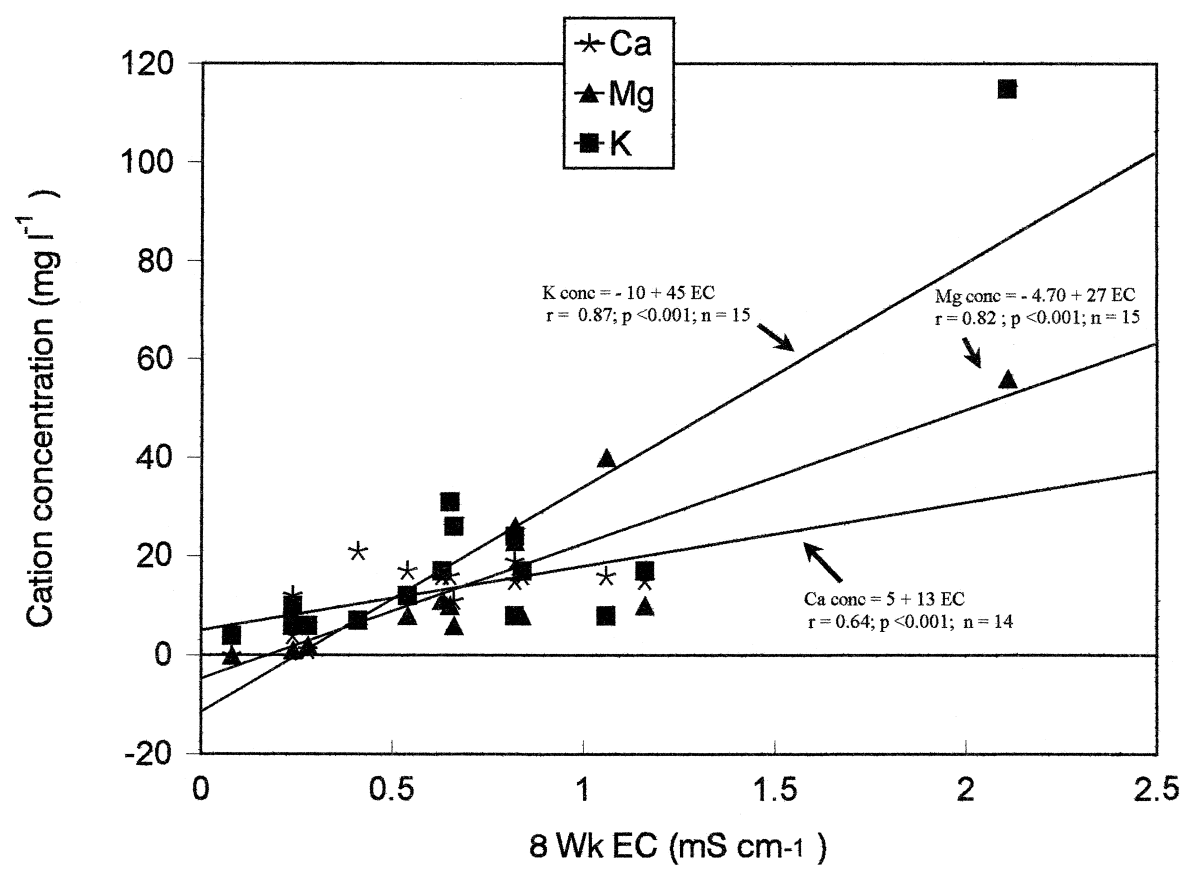

Fig. 10. Relationships between $\mathrm{K}, \mathrm{Ca}$ and $\mathrm{Mg}$ concentration in soil solution and the solution EC of 15 flooded West African soils at 8 weeks of flooding.

released during 15 weeks of flooding, soil 10 released the highest ammonium, with a mean value of $74 \mathrm{mg} \mathrm{N}^{-1}$ and soil 8 the least, with a mean value of 3 $\mathrm{mg} \mathrm{N}{ }^{-1}$ and clearly reflected the extent of variability in the soils examined with respect to their capacity to mobilize ammonium.

Based on the kinetics of ammonium release in the soils they can be grouped into three classes:

(i) The soils (soils 3, 6, 9 and 10) that released greater than $50 \mathrm{mg} \mathrm{N}^{-1}$ for most of the 15 weeks they were submerged may be considered best with respect to $\mathrm{N}$ supply and thus may need only modest application of fertilizer $\mathrm{N}$;

(ii) The soils (soils 1, 2, 4, 5, 7, 11, 12, 14 and 15) that mobilized ammonium between 15 and $50 \mathrm{mg} \mathrm{N}^{-1}$ on weekly basis are deficient in $\mathrm{N}$ and rice growing on them should greatly respond to added fertilizer $\mathrm{N}$;

(iii) The soils (soil 8 and 13) that released less than $15 \mathrm{mg}$ ammonium $\mathrm{N}^{-1}$, are considered acutely deficient in $\mathrm{N}$ supply and may need fertilizer $\mathrm{N}$ at both planting and as top dressing.

These results clearly establish that different soils may greatly differ in their capacity to release ammonium and thus may need different amounts of external $\mathrm{N}$ to achieve a target yield of rice (for a review see Sahrawat, 1983). Our earlier results with these soils also showed that they differ widely in their capacities to release ammonium during anaerobic incubation. Soil characteristics controlling 


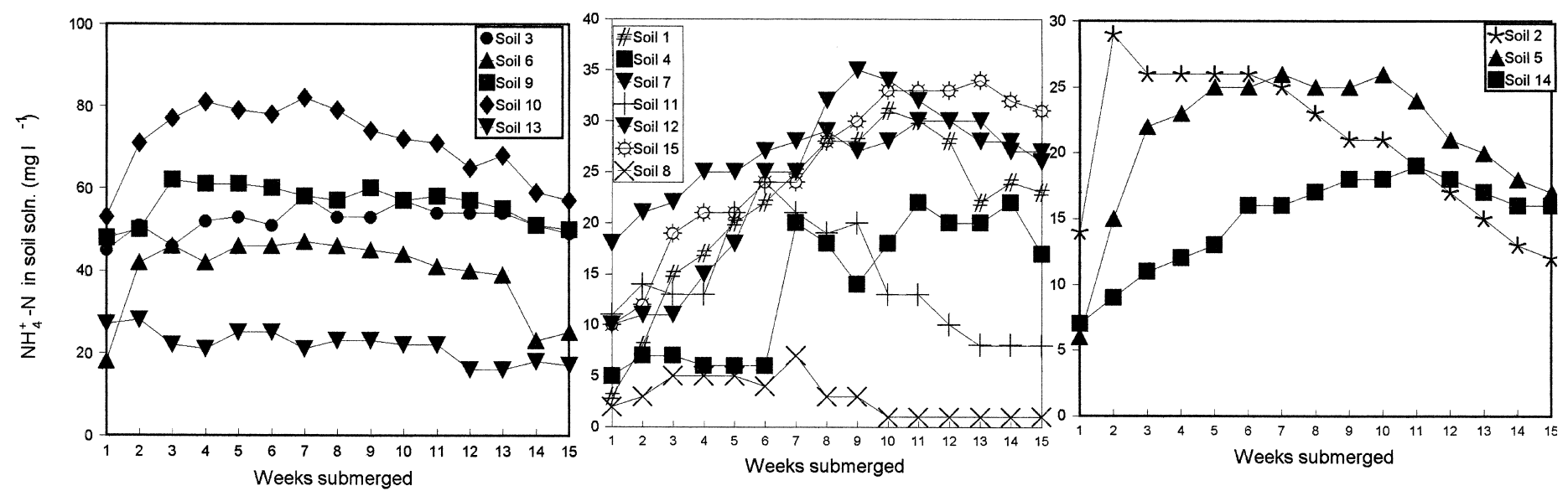

Fig. 11. Changes in the concentration of ammonium $\mathrm{N}$ in solution of 15 flooded West African soils. 
$\mathrm{N}$ supplying capacity and $\mathrm{N}$ management strategy considering $\mathrm{N}$ supplying capacity of the soils for wetland rice production were discussed (Narteh and Sahrawat, 1997).

\subsubsection{Changes in the concentration of $P$ in soil solution}

The increased availability of $\mathrm{P}$ as a result of flooding is of great benefit to lowland rice. It has been shown that $\mathrm{Fe}-\mathrm{P}$ is the most important source of $\mathrm{P}$ to wetland rice and this is the fraction of $\mathrm{P}$ which is greatly influenced by water regime (Ponnamperuma, 1965).

The soils examined mobilized low amounts of $\mathrm{P}$ in soil solution during the 15 weeks under submerged conditions (Fig. 12), and the highest concentration of $\mathrm{P}$ in soil solution $\left(0.63 \mathrm{mg} \mathrm{P}^{-1}\right)$ was recorded by soil 8 and 9 . It was further observed that the soil solution P showed three peaks: (i) soils 4 and 6 mobilized $>0.2 \mathrm{mg} \mathrm{P}^{-1}$ during the first three weeks of flooding, (ii) all soils, except

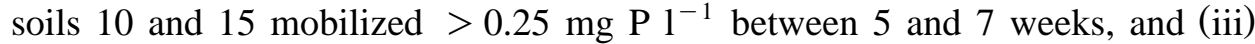
soils 2, 5, 8, 9 and 15 mobilized $\mathrm{P}$ in soil solution between 0.30 and $0.63 \mathrm{mg} \mathrm{l}^{-1}$ at 8 weeks of flooding.

The initial increase in soil solution $\mathrm{P}$ in submerged soils is attributed largely to the reduction of ferric phosphate to the more soluble ferrous phosphate and, to a lesser extent, to displacement of phosphate by the organic anions from ferric and aluminum phosphates. The subsequent decline in soluble $\mathrm{P}$ is caused by resorption of phosphate on sorption surfaces such as clay and hydroxides and an increase in $\mathrm{pH}$ (Ponnamperuma, 1965).

\subsubsection{Changes in the concentration of $K$ in soil solution}

At the first week of flooding, the concentration of $\mathrm{K}$ in soil solution ranged from 8 (soil 7) to 98 (soil 3) $\mathrm{mg} \mathrm{K}^{-1}$ and these values ranged between 6 (soil 8) and $110 \mathrm{mg} \mathrm{K}^{-1}$ at 15 weeks of flooding (Fig. 13). All soils with the exception of soil 3 recorded values of $\mathrm{K}$ concentrations in soil solution less than $25 \mathrm{mg} \mathrm{K} 1^{-1}$ indicating a need for $\mathrm{K}$ application from external sources in these soils. The requirement for $\mathrm{K}$ is further enhanced in soils that mobilize large amounts of Fe in soil solution (Sahrawat et al., 1996).

\subsubsection{Changes in the concentration of $\mathrm{Ca}$ and $\mathrm{Mg}$ in soil solution}

Changes in the concentrations of $\mathrm{Ca}$ and $\mathrm{Mg}$ in the soil solution of 15 soils are shown in Figs. 14 and 15. At the first week of flooding, the concentration of $\mathrm{Ca}$ in soil solution ranged between a trace (soils 4, 6 and 8) and $>500 \mathrm{mg} \mathrm{Ca}$ $1^{-1}$ (soil 3). By the 15 th week of flooding, the Ca concentration in solution was

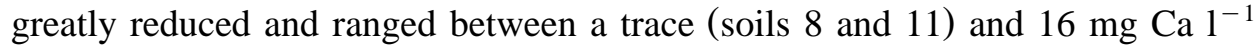
(Fig. 14). In general, the kinetics of $\mathrm{Ca}$ in solution reached a peak by the 4 th week and then the concentration fell. The decrease in the concentration of $\mathrm{Ca}$ in soil solution might have been caused by loss of $\mathrm{CO}_{2}$ and the reversion of soluble bicarbonate to insoluble carbonate. The highest variability in Ca concentrations in soil solution occurred at the 4 th week of flooding. 


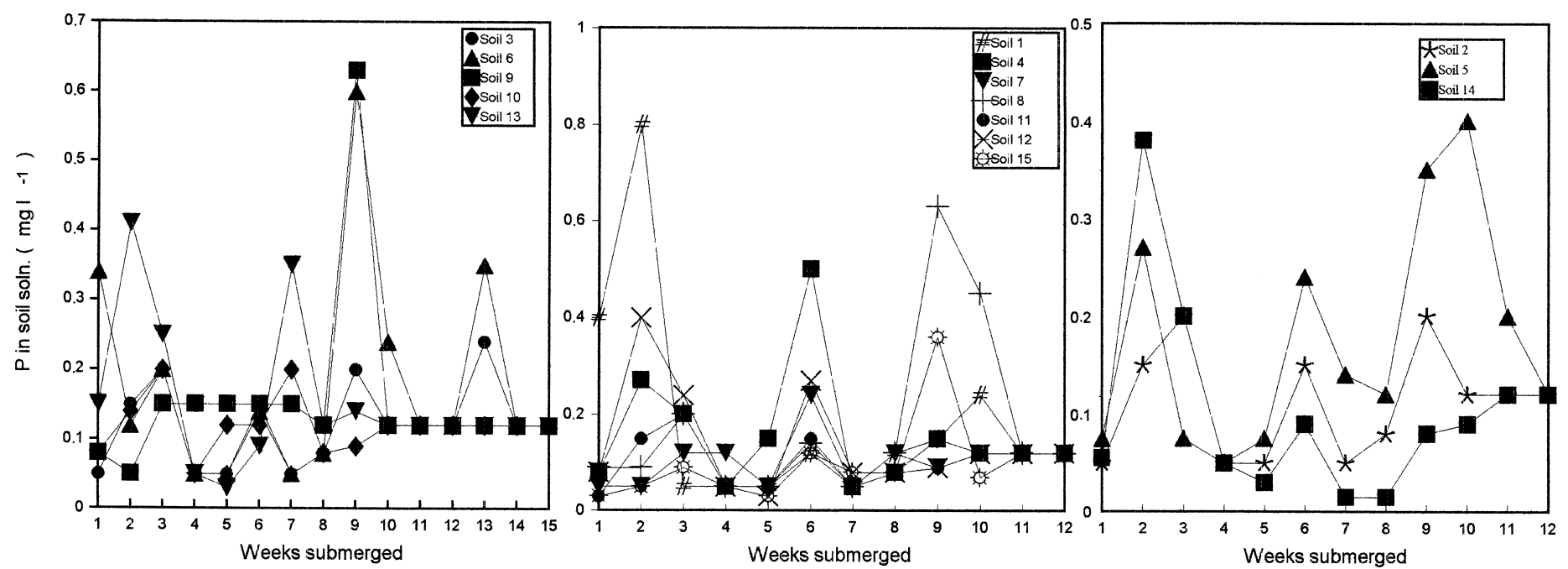

Fig. 12. Changes in the concentration of P in solution of 15 flooded West African soils. 


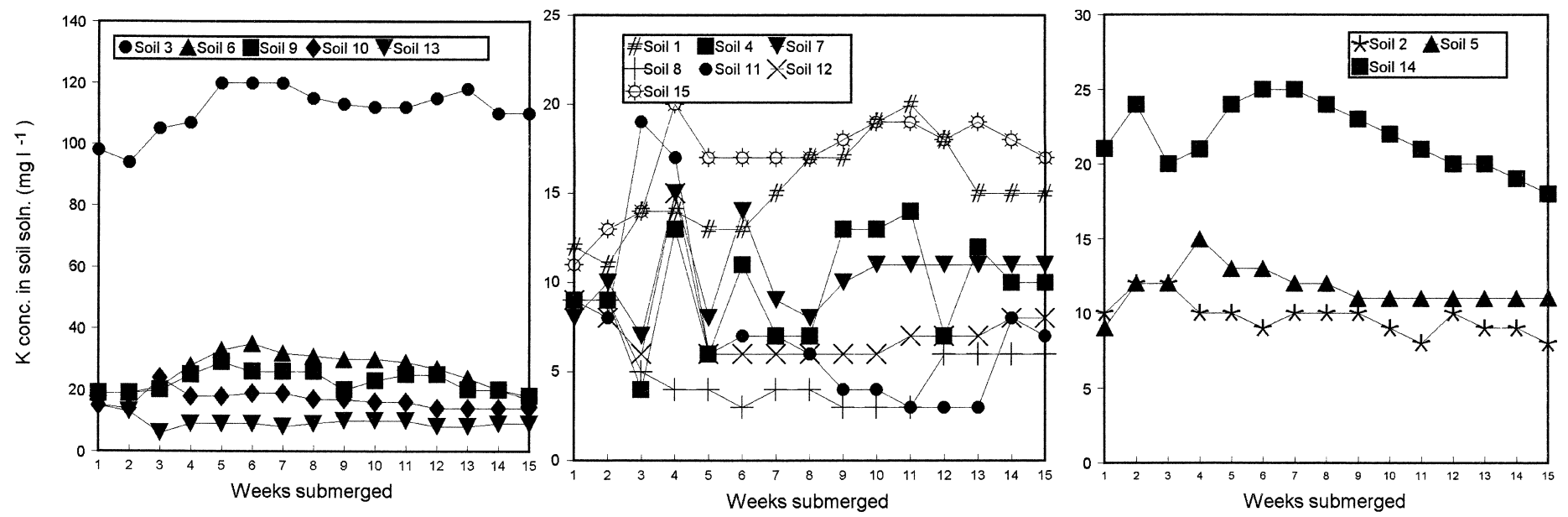

Fig. 13. Changes in the concentration of $\mathrm{K}$ in solution of 15 flooded West African soils. 


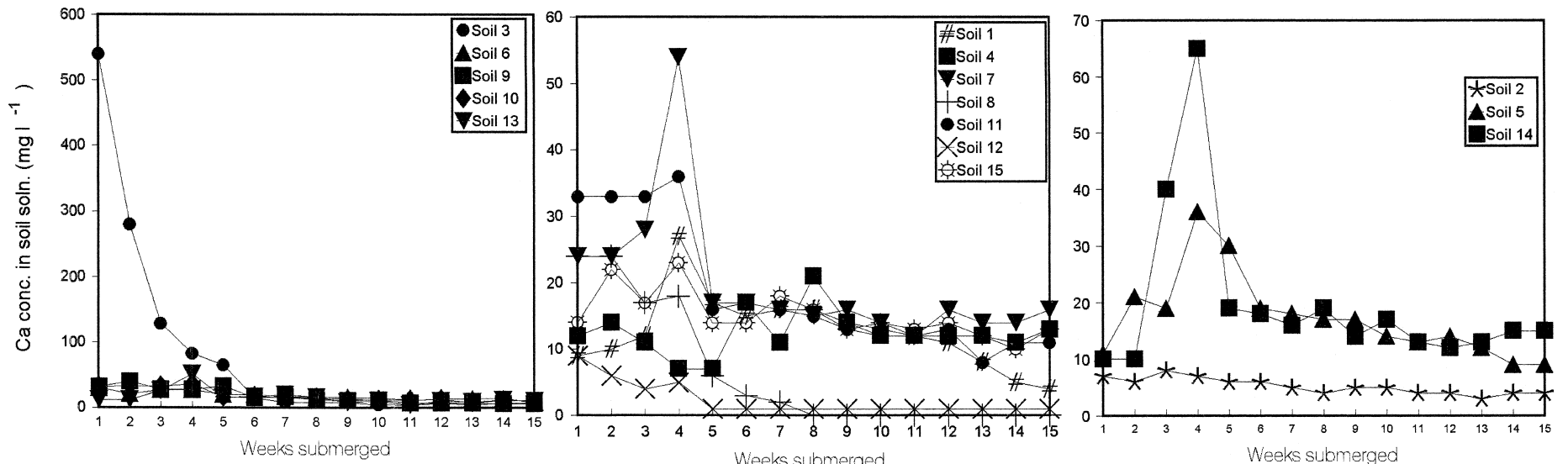

Fig. 14. Changes in the concentration of Ca in solution of 15 flooded West African soils. 


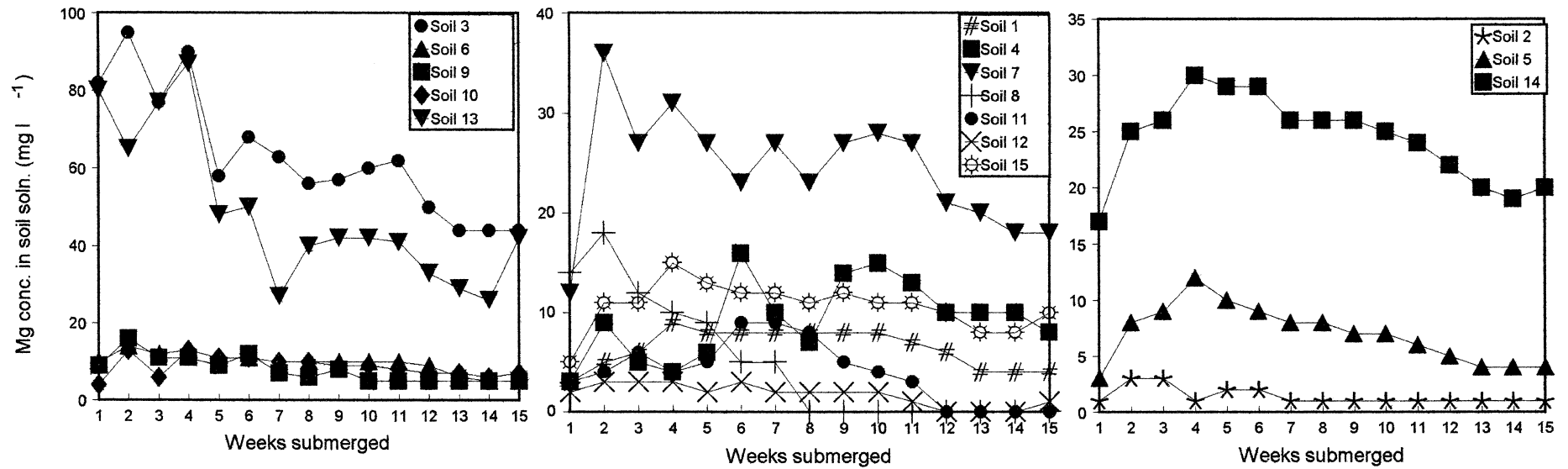

Fig. 15. Changes in the concentration of Mg in solution of 15 flooded West African soils. 
At the first week of flooding of the soils, the concentration of $\mathrm{Mg}$ in soil solution ranged between a trace (soil 5) and 77 (soil 3) $\mathrm{mg} \mathrm{Mg}^{-1}$, and by the 15th week the concentration ranged between a trace (soils 8 and 12) and $46 \mathrm{mg}$ $\mathrm{Mg}^{-1}$ (soil 3) (Fig. 15).

Assuming that $\mathrm{Ca}$ or $\mathrm{Mg}$ concentration of $>25 \mathrm{mg} \mathrm{l}^{-1}$ is critical for meeting the nutritional requirements of the rice plant, less than half of those examined (soils 3, 7, 9, 10, 13 and 14) met that requirement. Perhaps, more importantly, these soils may show an induced deficiency of these nutrients in iron-toxic soils

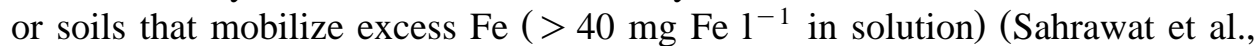
1996).

\subsubsection{Changes in the concentration of Fe(II) in soil solution}

The soils exhibited a wide range in the concentration of Fe(II) mobilized in solution under flooded conditions over the 15 weeks period (Fig. 16). Concentrations of $\mathrm{Fe}$ ranged from 1 (soil 7) to 58 (soil 6) $\mathrm{mg} \mathrm{Fe}^{-1}$. Based on the pattern of $\mathrm{Fe}(\mathrm{II})$ mobilized in soil solution, the 15 soils examined can be grouped into three classes:

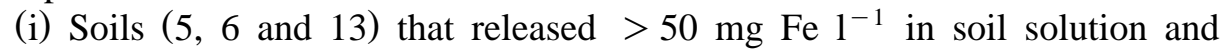
where the release of Fe peaked during the first 4 weeks of flooding. Delaying the transplanting of rice seedlings to 4 weeks after flooding (also termed presubmergence) on these soils may be a useful strategy for reducing iron toxicity to wetland rice;

(ii) Soils (1, 4, 9 and 10) that maintained a steady release of $\mathrm{Fe}$ in soil solution and released $\mathrm{Fe}$ in the range of $30-50 \mathrm{mg}^{-1}$ weekly during the 15 weeks. The Fe toxicity of rice on these soils may be difficult to manage because there will always be too much $\mathrm{Fe}$ in solution throughout the active growth period of the rice crop, provided the soil-plant conditions pertaining to Eh and $\mathrm{pH}$ promote the reduction of $\mathrm{Fe}$;

(iii) Soils in which the amount of Fe(II) in soil solution was mostly $<30 \mathrm{mg}$ $1^{-1}$. This group included upland, non Fe-toxic soils (soils 14 and 15) and other lowland swamp soils (soils 2, 7, 8, 11 and 12).

Organic matter acts as an electron donor in the reduction of $\mathrm{Fe}$ and high content of organic matter enhances the release of $\mathrm{Fe}(\mathrm{II})$ from $\mathrm{Fe}$ oxides (Ponnamperuma, 1972).

The equations which described the relationships between $\mathrm{Eh}, \mathrm{pH}$ and the release of $\mathrm{Fe}$ (II) in soil solution were also evaluated considering all soils at 2, 4 and 6 weeks of flooding. They were as follows:

At week 2

$$
\mathrm{Eh}=263-4.60 \log \mathrm{Fe}(\mathrm{II})-36 \mathrm{pH} ; \quad R^{2}=0.49
$$

At week 4

$$
\mathrm{Eh}=409-4.09 \log \mathrm{Fe}(\mathrm{II})-59 \mathrm{pH} ; \quad R^{2}=0.99
$$




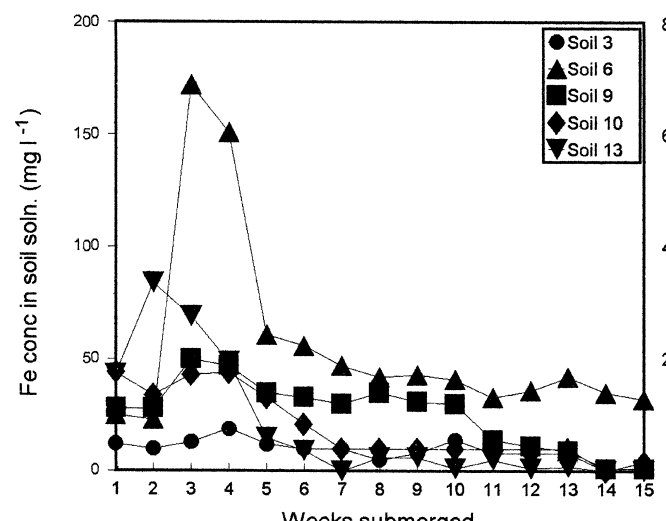

Weeks submerged

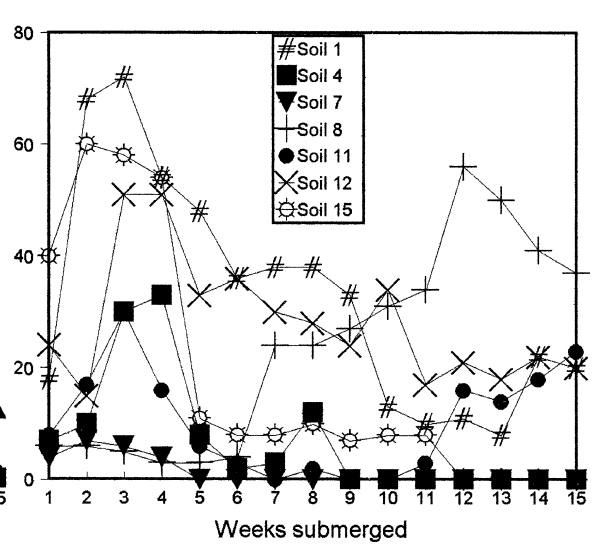

Weeks submerged

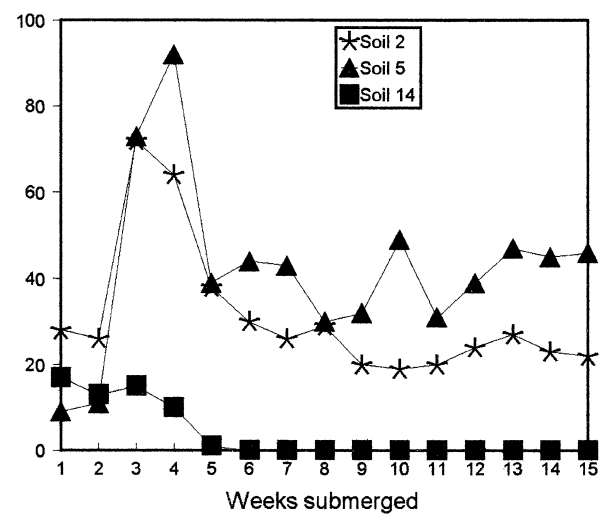

Weeks submerged 
At week 6

$$
\mathrm{Eh}=400-5.77 \log \mathrm{Fe}(\mathrm{II})-56 \mathrm{pH} ; \quad R^{2}=0.71
$$

These equations showed that by 4 th week of flooding maximum variability in the $\mathrm{Eh}-\mathrm{pH}-\mathrm{Fe}$ (II) relationship was predicted, and the variability accounted for was lower at 6 and 2 weeks of flooding when the soils were in a phase of dynamic equilibrium. A considerable narrowing down in the range of the electrochemical properties of soils was observed as a result of their flooding under water. The $\mathrm{pE}+\mathrm{pH}$ values of the anoxic water at 4th and 6th week of flooding when soil reduction was considered relatively stable (Table 4) support the finding that the soils were in a dynamic equilibrium. The recorded range in the values of $\mathrm{pE}+\mathrm{pH}$ of 6.10 to 7.84 indicated that these values fall in the range of $\mathrm{pE}+\mathrm{pH}$ required for the reduction of $\mathrm{Mn}$ and $\mathrm{Fe}$ oxides (Gotoh and Patrick, 1974; Genon et al., 1994).

Ponnamperuma et al. (1967) reported that the increase in the concentration of water soluble $\mathrm{Fe}$ (II) in flooded soils was caused by the reduction of ferric hydroxides and was described by the following equation:

$$
\mathrm{Eh}(\mathrm{mV})=103-60 \log \mathrm{Fe}(\mathrm{II})-180 \mathrm{pH} ; \quad r=-0.599 \quad(n=31)
$$

The equations describing the relationships among $\mathrm{Eh}, \mathrm{pH}$ and $\mathrm{Fe}(\mathrm{II})$ in soil solution for the West African soils differ from those reported by Ponnamperuma (1965). In our study, higher values for coefficient of correlation were achieved

Table 4

\begin{tabular}{|c|c|c|c|c|c|c|}
\hline \multirow[t]{2}{*}{ Soil no. } & \multicolumn{3}{|c|}{ At 4 weeks } & \multicolumn{3}{|c|}{ At 6 weeks } \\
\hline & $\mathrm{pE}$ & $\mathrm{pH}$ & $(\mathrm{pE}+\mathrm{pH})$ & $\mathrm{pE}$ & $\mathrm{pH}$ & $(\mathrm{pE}+\mathrm{pH})$ \\
\hline 1 & 0.54 & 6.43 & 6.97 & 0.52 & 6.48 & 7.00 \\
\hline 2 & 0.72 & 6.28 & 7.00 & 0.95 & 6.06 & 7.01 \\
\hline 3 & -0.32 & 7.31 & 6.99 & -0.20 & 7.18 & 6.98 \\
\hline 4 & 0.54 & 6.50 & 7.04 & 0.74 & 6.23 & 6.97 \\
\hline 5 & 0.33 & 6.75 & 7.08 & 0.56 & 6.43 & 6.99 \\
\hline 6 & 0.32 & 6.67 & 6.99 & 0.68 & 6.31 & 6.99 \\
\hline 7 & 0.13 & 7.12 & 7.25 & -0.016 & 6.99 & 6.97 \\
\hline 8 & 0.52 & 6.50 & 7.02 & 1.00 & 6.84 & 7.84 \\
\hline 9 & 0.44 & 7.44 & 7.88 & -0.05 & 7.04 & 6.99 \\
\hline 10 & 0.39 & 6.60 & 6.99 & 0.41 & 6.59 & 6.18 \\
\hline 11 & 0.86 & 6.07 & 6.93 & 0.32 & 6.67 & 6.99 \\
\hline 12 & 0.68 & 6.32 & 7.00 & 1.08 & 5.92 & 7.00 \\
\hline 13 & -0.76 & 7.76 & 7.00 & -1.08 & 6.83 & 6.91 \\
\hline 14 & -0.08 & 7.03 & 6.99 & 0.25 & 6.74 & 6.99 \\
\hline 15 & 0.64 & 6.35 & 6.99 & 0.63 & 6.37 & 7.00 \\
\hline
\end{tabular}

Soil solution $\mathrm{pH}, \mathrm{pE}$ and $\mathrm{pH}+\mathrm{pE}$ of 15 flooded West African soils at 4 and 6 weeks of flooding 
Table 5

The range, mean and standard error (SE) of Mn concentration $\left(\mathrm{mg} \mathrm{l}^{-1}\right)$ in solution of 15 flooded West African soils determined over 12 weeks

\begin{tabular}{rlll}
\hline Soil no. & Range & Mean & SE \\
\hline 1 & $0-5$ & 2.0 & 0.35 \\
2 & $0-1$ & 0.20 & 0.07 \\
3 & $0-4$ & 0.70 & 0.40 \\
4 & $0-2$ & 0.80 & 0.20 \\
5 & $0-3$ & 1.50 & 0.25 \\
6 & $0-2$ & 0.60 & 0.14 \\
7 & $0-9$ & 2.25 & 0.80 \\
8 & $0-5$ & 1.10 & 0.46 \\
9 & $0-4$ & 1.50 & 0.45 \\
10 & $0-7$ & 2.85 & 0.58 \\
11 & $0-1$ & 0.30 & 0.14 \\
12 & $0-1$ & 0.15 & 0.09 \\
13 & $0-13$ & 2.50 & 1.44 \\
14 & $0-14$ & 7.0 & 3.02 \\
15 & $0-2$ & 1.50 & 0.20 \\
\hline
\end{tabular}

for predicting the $\mathrm{Eh}-\mathrm{pH}-\mathrm{Fe}(\mathrm{II})$ relationships, especially at 4 and 6 weeks of flooding the soils when the Eh values were in the range conducive for $\mathrm{Fe}$ reduction.

Table 6

The range, mean and standard error (SE) of $\mathrm{Zn}$ concentration $\left(\mathrm{mg}^{-1}\right)$ in solution of 15 flooded West African soils determined over 5 weeks

\begin{tabular}{llll}
\hline Soil no. & Range & Mean & SE \\
\hline 1 & $0.0-0.50$ & 0.23 & 0.09 \\
2 & $0.0-0.30$ & 0.13 & 0.05 \\
3 & $0.0-0.22$ & 0.08 & 0.04 \\
4 & $0.0-0.36$ & 0.10 & 0.06 \\
5 & $0.0-0.20$ & 0.10 & 0.04 \\
6 & $0.0-0.43$ & 0.16 & 0.07 \\
7 & $0.0-0.40$ & 0.15 & 0.07 \\
8 & $0.0-0.44$ & 0.09 & 0.09 \\
9 & $0.0-0.70$ & 0.34 & 0.14 \\
10 & $0.0-0.35$ & 0.10 & 0.70 \\
11 & $0.0-0.60$ & 0.22 & 0.12 \\
12 & $0.0-0.40$ & 0.20 & 0.07 \\
13 & $0.0-0.23$ & 0.10 & 0.04 \\
14 & $0.0-0.20$ & 0.10 & 0.04 \\
15 & $0.0-0.20$ & 0.10 & 0.04 \\
\hline
\end{tabular}




\subsubsection{Changes in the concentration of $\mathrm{Mn}$ and $\mathrm{Zn}$ in soil solution}

The concentrations of $\mathrm{Mn}$ and $\mathrm{Zn}$ in soil solution for the 15 soils were low (Tables 5 and 6). The low concentrations of $\mathrm{Zn}$ and $\mathrm{Mn}$ in soil solution indicate a potential deficiency of these plant nutrients and, perhaps more importantly, the deficiencies of $\mathrm{Zn}$ and $\mathrm{Mn}$ to lowland rice may be further aggravated on Fe-toxic soils (Sahrawat et al., 1996).

\section{Conclusions}

Overall, our study showed that flooding affects electrochemical and chemical processes which, in turn, affect soil fertility in a dynamic manner. The main electrochemical changes that affect soil fertility include a decrease in redox potential or Eh and changes in soil and solution $\mathrm{pH}$. These changes are mainly controlled by organic matter and reducible-Fe contents of soils. The chemical changes influenced by flooding include the release of macro- and micronutrients which depend on soil characteristics, especially texture, organic matter and reducible Fe.

In general, all the 15 soils, with the exception of soil 3, were reduced only in the healthy range. Soil 3 was highly reduced and can cause problems to lowland rice through the production of reduction products. It was observed that soils benefitted to varying degrees in terms of release of plant nutrients and stabilization of $\mathrm{pH}$ in the narrower neutral range. Soils 3, 6, 7, 9, 10, 11, 12 and 13 which were relatively high in both organic $\mathrm{C}$ and extractable Fe (related to reducible $\mathrm{Fe}$ ), were generally more reduced and benefitted more. The rest of the soils were low in extractable Fe (soils 2, 5 and 14), organic $C$ (soils 1, 2, 4, 5 and 8 ) or both, and were relatively less reduced and, in turn, released lower amounts of plant nutrients as a result of flooding. Certainly, flooding soil is a great equalizer of soil chemical diversity and this process is driven mainly by organic matter and the reducible iron status of the soils.

\section{Acknowledgements}

We thank Dr. Abdoulaye Adam, Biometrician for his assistance in the statistical analysis of the data and African Development Bank for financial support through a research fellowship to L.T. Narteh. We also thank the two referees for very helpful and critical comments.

\section{References}

Andriesse, W., Fresco, L.O., 1991. A characterization of rice-growing environments in West Africa. Agric. Ecosyst. Environ. 33, 377-395. 
Bremner, J.M., 1965a. Total N. In: Black, C.A. et al. (Eds.), Methods of Soil Analysis. Agronomy, Vol. 9. Am. Soc. Agron., Madison, WI, pp. 1149-1178.

Bremner, J.M., 1965b. Inorganic forms of nitrogen. In: Black, C.A. et al. (Eds.), Methods of Soil Analysis. Agronomy, Vol. 9. Am. Soc. Agron., Madison, WI, pp. 1179-1237.

Brinkman, R., 1970. Ferrolysis, a hydromorphic soil forming process. Geoderma 3, 199-206.

Chapman, H.D., 1965. Cation exchange capacity. In: Black, C.A. et al. (Eds.), Methods of Soil Analysis. Agronomy, Vol. 9. Am. Soc. Agron., Madison, WI, pp. 891-901.

Cholitikul, W., Tyner, E.H., 1971. Inorganic phosphorus fractions and their relation to some chemical indices of phosphate availability for some lowland rice soils of Thailand. In: Proc. Int. Symposium on Soil Fertility Evaluation. Indian Soc. Soil Sci., New Delhi, India, pp. 7-20.

Ekpete, D.M., 1976. Evaluation of chemical methods for the determination of available phosphorus in waterlogged soils. Soil Sci. 121, 217-221.

FAO, 1988. FAO/UNESCO Soil Map of the World, Revised Legend. World Resources Report 60. Food and Agriculture Organisation of the United Nations, Rome.

Gee, G.W., Bauder, J.W., 1986. Particle size analysis. In: Klute, A. (Ed.), Methods of Soil Analysis, Part 1. Agronomy, Vol. 9. Am. Soc. Agron., Madison, WI, pp. 383-411.

Genon, J.G., de Hepcee, N., Delvaux, B., Dufey, J.E., Hennebert, P.A., 1994. Redox conditions and iron chemistry in highland swamps of Burundi. Plant Soil 166, 165-171.

Gotoh, S., Patrick, W.H. Jr., 1974. Transformation of iron in a waterlogged soil as influenced by redox potential and pH. Soil Sci. Soc. Proc. 38, 66-71.

Jackson, M.L., 1967. Soil Chemical Analysis. Prentice-Hall, New Delhi, India, p. 498.

Lindsay, W.L., Norvell, W.A., 1978. Development of DTPA (diethylenetriamine penta acetic acid) soil test for Zn, Fe, Mn and Cu. Soil Sci. Soc. Am. J. 42, 421-428.

Narteh, L.T., Sahrawat, K.L., 1997. Potentially mineralizable nitrogen in West African lowland rice soils. Geoderma 76, 145-154.

Nelson, D.W., Sommers, L.E., 1982. Total carbon, organic C, and organic matter. In: Page, A.L. et al. (Eds.), Methods of Soil Analysis, Part 2. Agronomy, Vol. 9 (second edn.). Am. Soc. Agron., Madison, WI, pp. 539-579.

Olsen, S.R., Sommers, L.E., 1982. Phosphorus. In: Page, A.L. et al. (Eds.), Methods of Soil Analysis, Part 2. Agronomy, Vol. 9 (second edn.). Am. Soc. Agron., Madison, WI, pp. 403-427.

Ponnamperuma, F.N., 1965. Dynamic aspects of flooded soils and the nutrition of the rice plant. In: International Rice Research Institute. The Mineral Nutrition of the Rice Plant. Johns Hopkins Univ. Press, Baltimore, MD, pp. 295-328.

Ponnamperuma, F.N., 1972. The chemistry of submerged soils. Adv. Agron. 24, 29-96.

Ponnamperuma, F.N., Tianco, E.M., Loy, T., 1967. Redox equilibria in flooded soils: I. The iron hydroxide systems. Soil Sci. 103, 374-382.

Sahrawat, K.L., 1983. Nitrogen availability indexes for submerged rice soils. Adv. Agron. 36, $415-451$.

Sahrawat, K.L., Mulbah, C.K., Diatta, S., DeLaune, R.D., Patrick, W.H. Jr., Singh, B.N., Jones, M.P., 1996. The role of tolerant genotypes and plant nutrients in the management of iron toxicity in lowland rice. J. Agric. Sci., Cambridge 126, 143-149.

Yu, T. (Ed.), 1985. Physical Chemistry of Paddy Soils. Science Press, Beijing and Springer-Verlag, Berlin Heidelberg. 